\title{
Abnormal expression of glucose-6-phosphatase in preterm infants
}

\author{
Robert Hume, Ann Burchell
}

\begin{abstract}
The hepatic microsomal glucose-6-phosphatase enzyme was studied in liver samples from 76 premature infants including 15 victims of sudden infant death syndrome. The data obtained were compared with glucose-6phosphatase activity in liver samples from 95 term infants. In the majority of preterm infants up to $\mathbf{3 5 0}$ days of age the activity of the glucose-6-phosphatase enzyme was at or below the extreme low limit of the normal range in term infants. The premature infants with the lowest hepatic microsomal glucose-6phosphatase activities are likely to be at risk of hypoglycaemic episodes during periods of relative starvation or stress.
\end{abstract}

(Arch Dis Child 1993;68:202-4)

It has been proposed that genetic deficiencies that have the potential to lead to severe hypoglycaemic episodes, if undiagnosed, may have the potential to cause sudden and unexpected death in infancy ${ }^{1}$ and many different biochemical abnormalities have been found in tissues removed at necropsy of infants dying of sudden infant death syndrome (SIDS). ${ }^{2-11}$ The hepatic microsomal glucose-6-phosphatase system catalyses the final step of the two pathways of liver glucose production (gluconeogenesis and glycogenolysis) and any deficiency resulting in abnormally low glucose-6-phosphatase activity has the potential to lead to hypoglycaemic episodes. We have previously reported 11 cases of abnormalities in the glucose-6-phosphatase system in association with raised hepatic glycogen in term infants who died suddenly and unexpectedly. ${ }^{12}$ Within this group there was one case of type la glycogen storage disease with no immunodetectable glucose-6-phosphatase protein; one case of type $\mathrm{lb}$ and two cases of type lc. Of the remaining seven cases what was surprising was that they all had abnormally low glucose-6-phosphatase enzyme activity and low amounts of immunodetectable glucose-6phosphatase enzyme protein of normal molecular weight. A more recent study of the ontogeny of the glucose-6-phosphatase enzyme in term infants raises the possibility that some of those cases could be delayed or abnormal development of the glucose-6-phosphatase enzyme rather than cases of partial type la glycogen storage disease. ${ }^{13}$

Here we report that the pattern of abnormally low glucose-6-phosphatase enzyme activity with low amounts of immunodetectable glucose-6phosphatase protein of normal molecular weight is common in infants born prematurely including infants succumbing to SIDS. Glucose-6phosphatase activity is low in the first few postnatal days but persistance into infancy has not previously been described and could exacerbate the onset of hypoglycaemia in those infants at times of stress or starvation.

\section{Patients and methods}

\section{PATIENTS}

Liver tissue was obtained at necropsy from 116 premature infants (24-36 weeks' gestation) who died up to 12 months after birth. Thirty two of the infants died within 24 hours of delivery and 20 died between 24 and 48 hours of delivery as a consequence of immature pulmonary function or intraventricular haemorrhage. Sixty four of the infants died later in the first year of life. In 32 of these cases no attributable cause of death could be found at necropsy and they have been considered to represent cases of SIDS. Control data from 95 term infants who were previously described have also been included..$^{13}{ }^{14}$ In early hospital deaths the mean interval between the time life was pronounced extinct and the time of necropsy was six hours (2-12 hours) during which time the bodies had been refrigerated. In some late postnatal deaths it was not possible to assess the specific time of death because some of the babies died suddenly and unexpectedly at home. In 171 out of the 211 liver samples described over $75 \%$ of the microsomes were intact on biochemical investigation and there was no evidence of even slight proteolysis. ${ }^{13-15}$ All liver samples that did not meet these two criteria were discarded (40 samples) leaving 76 samples from premature infants that were further analysed along with the 95 samples from term infants.

\section{METHODS}

Unfrozen hepatic samples were used to prepare microsomes as previously described. ${ }^{16}$ Glucose6-phosphatase activity was assayed at $30^{\circ} \mathrm{C}$ as previously described. ${ }^{17}$ Microsomes were disrupted with histone $2 \mathrm{~A} .{ }^{18}$ Non-specific hydrolysis of glucose-6-phosphate was assayed and corrected for as in previous studies. ${ }^{17-19}$ The proportions of intact and disrupted microsomes were estimated by assays using $1 \mathrm{mmol} / \mathrm{l}$ mannose-6-phosphate as substrate for glucose6-phosphatase and/or 1 napthol as substrate for uridine diphosphate glucuronosyltransferase (both only produce activity in disrupted microsomes). ${ }^{20} 21$ Protein and glycogen were measured as described by Peterson ${ }^{22}$ and Van Handel ${ }^{23}$ respectively. 
Ethical approval for this study was given by the paediatric/reproductive medicine ethics of medicine research subcommittee of Lothian Health Board and by Tayside Health Board ethical committee.

\section{Results}

The activity of the glucose-6-phosphatase enzyme (measured in fully disrupted microsomes) in the majority of preterm infants between 0-5 days after birth remained low (below $0.2 \mu \mathrm{mol} / \mathrm{min} / \mathrm{mg}$ protein) but a few infants in a 24 hour period around day 2 had higher levels of activity (fig 1). The pattern of glucose-6-phosphatase activity in preterm infants is quite different to the pattern of activity that we have previously shown in term infants. ${ }^{13}$ In term infants the activity of the glucose-6phosphatase enzyme rises rapidly after birth and reaches normal adult activities (range $0 \cdot 19-0.65 \mu \mathrm{mol} / \mathrm{min} / \mathrm{mg}$ protein) within the first two to three days after birth. The majority of values of glucose-6-phosphatase activity in preterm infants between $0-5$ days after birth (fig 1 ) are therefore lower than the values found in term infants of the same age. ${ }^{13}$ Hepatic glycogen content in the $\mathbf{9 6}$ term infants was less than 800 $\mu \mathrm{g} / \mathrm{mg}$ protein in all samples. In the preterm infants, while the majority had a hepatic glycogen content less than $800 \mu \mathrm{g} / \mathrm{mg}$ protein some were not, perhaps, reflecting immaturity of hepatic glycogenolysis and gluconeogenesis. In term infants, from 3-352 postnatal days, the lower limit of the normal range of glucose-6phosphatase activity was remarkably constant at approximately $0.2 \mu \mathrm{mol} / \mathrm{min} / \mathrm{mg}$ protein (fig 2). In contrast, over the same time period the vast majority of preterm infants were on, or below, the lower limit of the normal term range (fig 2) with no obvious differences in glucose-6phosphatase activity between cases with an attributable cause of death and those of SIDS.

\section{Discussion}

We have shown that abnormally low enzyme activity and expression of glucose-6-phosphatase enzyme in preterm infants is surprisingly common (figs 1 and 2). In contrast low activity is



Figure 1 Theactivity of the glucose-6-phosphatase in premature infants. All data were specific activities of glucose-6-phosphatase (VMAxvalues) in fully disrupted liver microsomes; activity is expressed as umol/min/mg protein.

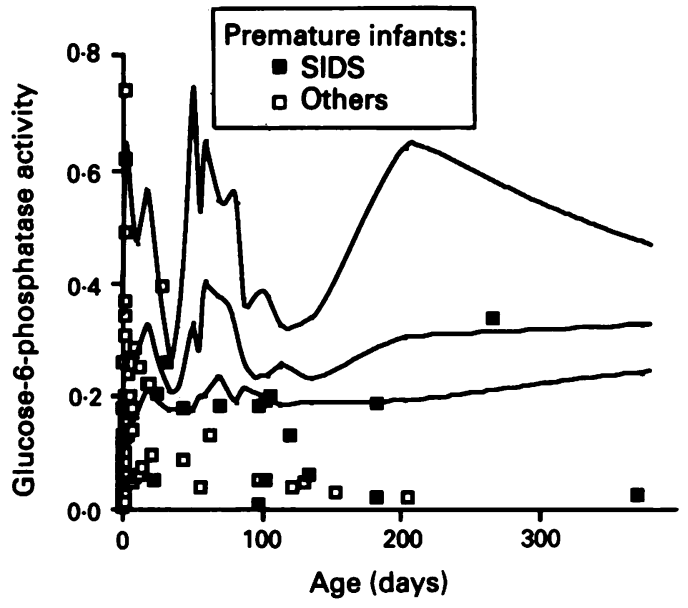

Figure 2 A comparison of the glucose-6-phosphatase activity in term and premature infants. All data are specific activities of glucose-6-phosphatase $\left(V_{M A X}\right)$ in fully disrupted liver microsomes; activity is expressed as $\mu \mathrm{mol} / \mathrm{min} / \mathrm{mg}$ protein. Lines are the mean and upper and lower limits of the normal range of the values found in 94 term infants.

rare in full term infants, ${ }^{13}$ although this may be more common in those term infants who are categorised as having died of SIDS. ${ }^{12}$

In previous studies we have shown that in rat liver microsomes the glucose-6-phosphatase enzyme activity is very low at birth, but thereafter during the first few postnatal days, the activity of glucose-6-phosphatase enzyme overshoots to values several times higher than adult activities. ${ }^{24}$ In contrast, in term infants, the pattern is different with a rise from birth to adult values by 3 days of age, which are thereafter sustained ${ }^{13}$ - that is, there is no overshoot. Figure 1 shows that some preterm infants, around 2 days of age, have higher glucose-6-phosphatase activities than at any other time. This pattern is reminiscent of the postnatal overshoot in glucose-6-phosphatase activity previously seen in term rats ${ }^{24}$ and may reflect the relative precocity of term rats at birth compared with humans. How closely the postnatal development of glucose-6-phosphatase in preterm humans resembles that of term rats cannot be determined by serial liver biopsy for obvious ethical reasons.

In the majority of preterm infants after three postnatal days, the glucose-6-phosphatase enzyme activities are below the extreme limit of the normal term range with only a few infants above the lower extreme (fig 2). The high brain to body weight ratio in premature infants and the linear requirement of gestational brain size to glucose requirement ${ }^{25}$ would suggest that higher, not lower, hepatic glucose output is required in premature infants. Those preterm infants with low glucose-6-phosphatase values are likely to be at risk of hypoglycaemic episodes during periods of relative starvation or stress. This is critical for those preterm infants with glucose-6-phosphatase activities below $0.05 \mu \mathrm{mol} / \mathrm{min} / \mathrm{mg}$ protein and within the range normally diagnostic for partial or complete type la glycogen storage disease. ${ }^{12141626}$

We believe that the abnormal patterns of postnatal glucose-6-phosphatase enzyme activitives in preterm infants are a likely consequence 
of disordered perinatal regulation. It is not known how long this state of delayed or abnormal development persists, although we have previously reported a 19 year old, who was born prematurely, and who had low glucose-6phosphatase enzyme activity with low amounts of immunodetectable glucose-6-phosphatase protein. ${ }^{26}$ The risks of hypoglycaemia in infants are the same whether the deficiencies in the glucose-6-phosphatase system or indeed other key gluconeogenic enzymes are genetic or developmental in nature. We are now using animal systems to model premature and term developmental delay with the aim of therapeutic manipulation of expression of glucose-6phosphatase enzyme.

We thank Procurators Fiscal, Dr J M Anderson, Dr A D Bain, Dr J E Bell, Professor A Busutil, Dr $M$ W H Coughtrie, Dr $M$ Giles, Mr A Glancy, Dr D Hopwood Dr R T Jung, Dr L A Laing, Dr $\mathrm{H}$ Lyall, Dr J Pears, Dr A Shepherd, and Dr I D Waddell for tissue samples, help or advice, and Mrs L Gibb, Mrs P Houston, and Miss D Henderson for technical assistance.

This work was supported by a grant from the Scottish Home and Health Department to $\mathrm{AB}$ and $\mathrm{RH}$ and equipment grants from Tenovus (Scotland), Anonymous Trust, and Research Trust for Metabolic Diseases in Children to AB. AB is a Lister Institute research fellow.

1 Emery JL, Howat AJ, Variend S, Vawter GF. Investigation of inborn errors of metabolism in unexpected infant deaths. Lancet 1988;ii:29-31.

2 Allison F, Bennett MJ, Variend S, Engel PC. Acylcoenzyme A dehydrogenase deficiency in heart tissue from infants who died unexpectedly with fatty change in the liver. $B M \mathcal{J}$ died unexpectedly

3 Howat AJ, Bennett MJ, Variend S, Shaw L, Engel PC. Defects of metabolism of fatty acids in the sudden infant Defects of metabolism of fatty acids in
death syndrome. $B M 7$ 1985;290:1771-3.

4 Hallock J, Morrow G, Karp LA, Barness LA. Post mortem diagnosis of metabolic disorders. The finding of maple syrup urine disease in a case of sudden and unexpected death in infancy. Am $\mathcal{F}$ Dis Child 1969;118:649-51.

5 Russell MA, Optiz JM, Viseskul C, Gilbert EF, Bargman GJ. Sudden infant deaths due to congenital adrenal hypoplasia. Arch Pathol Lab Med 1977;101:168-9.

6 Howat AJ, Bennett MJ, Variend S, Shaw L. Deficiency of medium chain fatty acylcoenzyme A dehydrogenase pre-
senting as the sudden infant death syndrome. $B M \mathcal{F} 1984$; senting as

7 Sturner WQ, Susa JB. Sudden infant death and liver phosphoenolpyruvate carboxykinase deficiency. Forensic Sci Int 1980;16:19-28.

8 Harpey JP, Charpentier C, Coude M, Divry P, Patureau-
Jouas $M$. Sudden infant death syndrome and multiple acyl-coenzyme A dehydrogenase deficiency, ethylmalonicadipic aciduria, or systemic carnitine deficiency. $\mathcal{F}$ Pediatr 1987;110:881-4.

9 Harpey JP, Charpentier C, Paturneau-Jouas M. Fatty acid $\beta$-oxidation defects and sudden infant death. Lancet 1987; 163.

10 Chalmers RA, English N, Hughes EA, Nobel-Jamieson C, Wigglesworth JS. Biochemical studies on cultured skin fibroblasts from a baby with long chain acyl CoA dehydrogenase deficiency presenting as sudde

11 Polak JM, Wigglesworth JS. Islet-cell hyperplasia and sudden infant death. Lancet 1976;ii:570-1.

12 Burchell A, Bell JE, Busuttil A, Hume R. Hepatic microsomal glucose-6-phosphatase system and sudden infant death syndrome. Lancet 1989;ii:291-4.

13 Burchell A, Gibb L, Waddell ID, Giles M, Hume R. The ontogeny of the human hepatic glucose-6-phosphatase proteins. Clin Chem 1990;36:1633-7.

14 Burchell A, Waddell ID. The molecular basis of the genetic deficiencies of five of the components of the glucose-6deficiencies of five of the components of the glucose-6phosphatase syste
1992 (in press)

15 Coughtrie MWH, Blair JNR, Hume R, Burchell A Improved procedure for the preparation of hepatic microsomes to be used in the in vitro diagnosis of inherited disorders of the glucose-6-phosphatase system. Clin Chem 1991;37:739-42.

16 Burchell A, Jung RT, Lang CC, Bennett W, Shepherd AN. Diagnosis of type la and type lc glycogen storage diseases in adults. Lancet 1987; $\mathrm{i}: 1059-62$.

17 Burchell A, Hume R, Burchell B. A new microtechnique for the analysis of the human hepatic microsomal glucose-6 the analysis of the human hepatic microsomal glucose

phosphatase system. Clin Chim Acta 1988;173:183-92.
18 Blair JNR, Burchell A. The mechanism of histone activation of the hepatic microsomal glucose-6-phosphatase system: a novel method to assay glucose-6-phosphatase activity. Biochim Biophys Acta 1988;964:161-7.

19 Burchell A, Burchell B. Stabilisation of partially purified glucose-6-phosphatase by fluoride: is enzyme inactivation caused by dephosphorylation? FEBS Lett 1980;113:180-4.

20 Arion WJ, Ballas LM, Lange AJ, Wallin BK. Microsoma membrane permeability and the hepatic glucose-6 phosphatase system. F Biol Chem 1976;251:4901-7.

21 Scragg I, Arion WJ, Burchell B. Microsomal membrane integrity and expression of UDP-glucuronyltransferase integrity and expression of UDP-glucuronyltransferase activity in response to UDP-N acetylglucosamine. In: Matern S, Bock WK, Gerok W, eds. Advances in
conjugation. Lancaster: MTP Press, 1985:390-1.

22 Petersen GL. A simplification of the protein assay methods of Lowry et al which is more generally applicable. Anal Biochem 1977;83:346-56.

23 Van Handel E. Estimation of glycogen in small amounts of tissue. Anal Biochem 1965;11:256-65.

24 Burchell A, Leakey JEA. Development of the rat hepatic microsomal glucose-6-phosphatase system and its glucocorticoid inducibility. Biol Neonate 1988;54:107-15.

25 Aynsley-Green A, Soltész G. Hypoglycaemia in infancy and childhood. In: Aynsley Green A, Chambers IL, eds. Current reviews in paediatrics. Edinburgh: Churchill Livingstone reviews.

26 Pears JS, Lung RT, Hopwood D, Waddell ID, Burchell A. Ten cases of symptomatic adult hypoglycaemia due to hepatic glycogen metabolising abnormalities. $Q \mathcal{f} \mathrm{Med}$ 1992;299:207-22. 